\title{
Mental health: the missing link in primary care? Health for All by the Year 2000 revisited
}

\author{
K. Saeod, 'R. Gator, ${ }^{2}$ M.H. Mubbashar' and N. Maqsood?
}

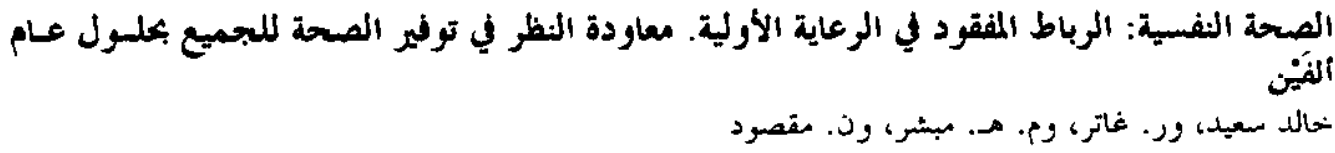

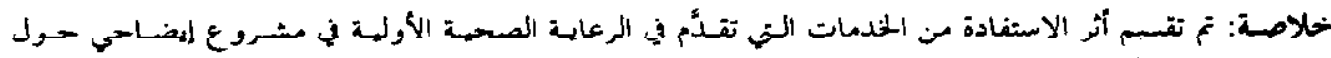

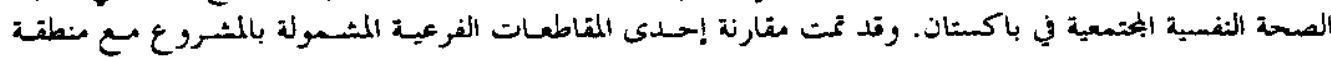

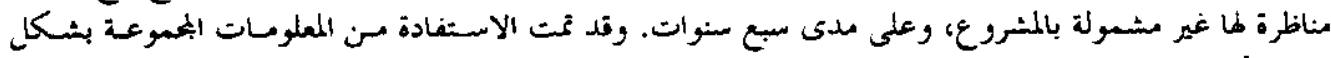

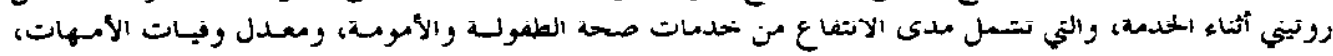

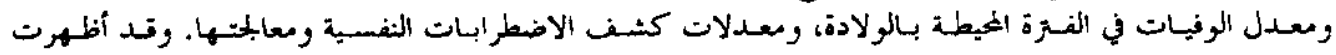

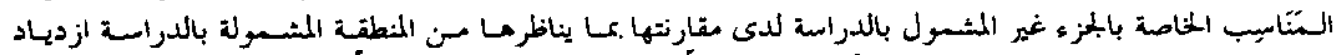

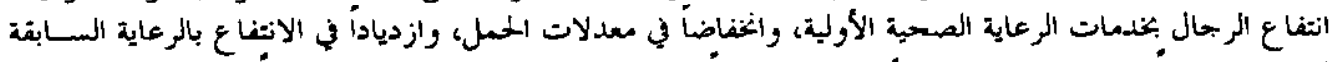

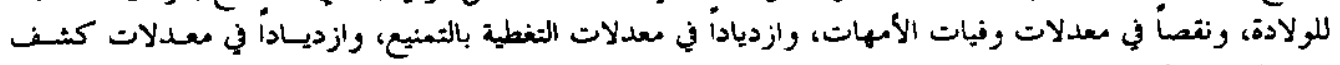

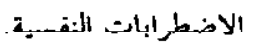

ABSTRACT The effects on the uptake of services offered in primary health care of a demonstration community mental health project in Pakistan were assessed. A subdistrict with the project was compared with a matched area without the project over 7 years. Routinely collected information on service use was used, including the detection and treatment of mental disorders. Compared with the comparison subdistrict, the index subdistrict showed an increase in use of primary care by men, reduction in pregnancy rate, increased use of antenatal care, reduced maiernal mortalty, increased immunization coverage, and increased detection and treatment of mental disorders.

Santé mentalo : le maillon manquant dans les soins de santé primaires ? La Santé pour tous d'lci I'an 2000 revisittée

RESUME On a procédé à une évaluation des effets d'un projet de démonstration dans le domaine de la santé mentale communautaire au Pakistan sur le degré d'utilisation des services offerts dans les solns de sante primaires. Un sous-district doté du projet a été comparé avec une zone appariée ne disposant pas du projet sur une période de 7 ans. Des informations recueillies de façon systématique sur l'utilisation des services ont été utiliś́es, notamment sur le dépistage et le traitement des troubles mentaux. Par rapport au sous-district servant de point de comparaison, le sous-district index a montré une augmentation de l'utilisation des soins de santé primaires par les hommes, une réduction du taux de grossesse, une utilisation accrue des soins anténatals, une mortalité maternelie réduite, une couverture vaccinale améliorée et une augmentation du dépistage et du traitement des troubles mentaux.

\footnotetext{
'Institute of Psychiatry, WHO Collaborating Centre for Mental Health Research and Training. Fawalpindi Medical College, Rawalp/ndl, Pak/stan.

'School of Psychiatry and Behavioural Sciences, University of Manchester, Royal Preston Hospital,

Preston, England.
}

${ }^{\ddagger}$ Sheik Zayed Hospital, Rahim Yar Khan, Pakistan.

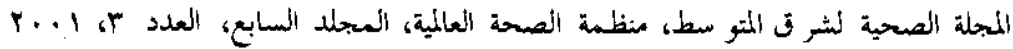




\section{Introduction}

The Alma Ata declaration, which included mental health care as an essential component of the primary health care strategy for Health for All by the Year 2000, has resulted in mixed achievements [ 1$]$. From proclamation to execution, the way has not been easy for the integration of mental health into primary care. Despite the energetic efforts of the World Health Organization and other international agencies, other programmes, e.g. immunization and reproductive health programmes have also met with variable success, and primary care facilities remain underused. Some countries have introduced mental health into their national health priorities, while others have not moved heyond the planning phase [2]. What then is the stumbling block? We suggest that it is a lack of confidence in using a psychosocial approach to health and health care delivery.

This paper reports the impact of the introduction of mental health into primary health care in a developing country. The National Mental Health Programme of Pakistan was formulated in 1987 to carry forward the process of developing and evaluating mental health services [3]. The aims of the programme are to prevent and treat mental disorders and their associated disabilities, to apply mental health technology and hehavioural science to improve general health services, and to use mental health principles and a psychosocial approach to improve the quality of life nationwide.

To achieve these aims, a demonstration project was set up in the nural, periurban subdistrict of Gujar Khan in the Rawalpindi district of Pakistan in 1985 [4-7]. The project did not restrict itself to the health sector but extended to involve the community, schools $[8,9]$, traditional healers, reli- gious leaders, voluntary organizations and local politicians. The implementation of the project followed four phases: collection of sociodemographic information, training, supervision and monitoring, and evaluation.

Here we report on the effects of the demonstration project on the uptake of services offered in primary health care by examining routinely collected data from two subdistricts: one included in the project and one not. The hypotheses were that the community mental health project would improve uptake of primary health care (PHC), including maternal and child health services, reduce mortality associated with childbirth and increase detection and treatment of mental disorders.

\section{Methods}

The study retrospectively compared two subdistricts over 7 years. The demonstration project started in the index subdistrict of Mandra during the second year of this period. A comparison subdistrict, Taxilla, was matched for sociodemographic profile and provision of health, education and communication facilities. Both subdistricts are a mix of rural and periurban communities. Family size is large and extended, with low literacy rates particularly for females. A large proportion of the men are employed in jobs that require them to be away from home for long periods.

Data were extracted from 140 registers, including outpatients, maternal and child health services, birth, mortality and immunization records. These were analysed by sex and age group (0-19 years, 20-54 years and over 55 years of age). Using projections of the population at risk in each subdistrict from the 1981 census, annual rates were calculated for pregnancy, infant mortality, maternal mortality, antenatal 
care, assisted deliveries, immunization, primary care attendance, detection of mental disorder in primary care and psychotropic prescribing.

\section{Results}

Complete data were available for the index subdistrict from 1985 to 1991 and for the comparison subdistrict from 1986 to 1991 (Table 1).

At the start of the project, the attendance rate for women was twice that of men in both subdistricts. This persisted in the comparison area, while in the index subdistrict the attendance rate in men rose to equal that of women.

The pregnancy rate in the index subdistrict decreased during the study period, while in the comparison subdistrict, there was an increase in the pregnancy rate.

In both centres the uptake of antenatal care rose progressively; however there was a marked and sustained increase in the uptake of antenatal care in the index subdistrict during the first 2 years of the project. Similar trends occurred for the rate of assisted deliveries.

Infant mortality rates dropped steadily from 14 per 100 births in 1985 to less than 10 per 100 births in 1991 in both subdistricts. Maternal mortality also fell during the period, but the reduction occurred earlier in the index subdistrict and remained half that of the comparison subdistrict.

In the comparison subdistrict, immunization coverage rose steadily for boys and girls. In the index subdistrict immunization rates for boys increased sharply in the early years of the project and continued to rise. The rates for girls rose more steadily than boys, but at a greater rate than in the comparison subdistrict.
There were clear differences in the detection and prescribing rates for mental disorders in the index and comparison subdistricts by the PHC personnel. Detection rates were very low in both subdistricts at the start of the project. They remained low in the comparison subdistrict, while there was a marked increase in the index subdistrict. Closer examination by age showed a slow increase in detcetion among those over 60 years until 1989 , followed by a major increase in 1990 when mental disorders of this age group werc targeted in the training and support provided by the project. Rates of psychotropic prescribing paralleled detection rates.

\section{Discussion}

The concept underpinning the community mental health project is to use mental health principles to improve general health status and enhance quality of life. This project has demonstrated that the beneficial effects are not confined to the detection and treatment of mental illness, but have an impact on the extent to which other services offered by PHC are used.

The introduction of the project resulted in an increase in attendance at primary care by men, and increased use of maternal and child health services by women, as shown by an increased use of antenatal and immunization facilities, and reduced rates of pregnancy and maternal mortality.

The project was set against the backdrop of concerted national drives for immunization and maternal and child health services. The beneficial effects of these are reflected in the improvement in health indices in the comparison subdistrict. Differences between the two subdistricts can be attributed to the integration of mental health in PHC.

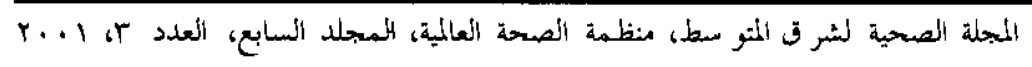




\begin{tabular}{|c|c|c|c|c|c|c|c|}
\hline \multirow[t]{2}{*}{ Veriable } & \multicolumn{7}{|c|}{ Index subdistrict: Mandra } \\
\hline & 1985 & 1986 & 1987 & 1988 & 1989 & 1990 & 1991 \\
\hline PHC attendance $/ 1000$ men & 133 & 140 & 190 & 247 & 132 & 130 & 228 \\
\hline $\begin{array}{l}\mathrm{PHC} \text { attendance } / 1000 \\
\text { women }\end{array}$ & 177 & 184 & 268 & 227 & 204 & 165 & 213 \\
\hline $\begin{array}{l}\text { Pregnancies } / 1000 \\
\text { women agod } \\
20-54 \text { vears }\end{array}$ & $\begin{array}{c}144 \\
(137-152)\end{array}$ & $\begin{array}{c}128 \\
(12)-135)\end{array}$ & $\begin{array}{c}139 \\
(132-146)\end{array}$ & $\begin{array}{c}133 \\
(130-144)\end{array}$ & $\begin{array}{c}137 \\
(130-144)\end{array}$ & $\begin{array}{c}129 \\
(122-135\end{array}$ & $\begin{array}{c}120 \\
(113-126\end{array}$ \\
\hline $\begin{array}{l}\text { Antenatal care } / 100 \\
\text { births }\end{array}$ & $\begin{array}{c}47 \\
(45-49)\end{array}$ & $\begin{array}{c}56 \\
(54-59)\end{array}$ & $\begin{array}{c}67 \\
(65-70)\end{array}$ & $\begin{array}{c}63 \\
(61-66)\end{array}$ & $\begin{array}{c}63 \\
(60-65)\end{array}$ & $\begin{array}{c}61 \\
(58-63)\end{array}$ & $\begin{array}{c}69 \\
(6 /-/ 2)\end{array}$ \\
\hline $\begin{array}{l}\text { Assisted deliveries/100 } \\
\text { births }\end{array}$ & $\begin{array}{c}26 \\
(24-28)\end{array}$ & $\begin{array}{c}30 \\
(28-32)\end{array}$ & $\begin{array}{c}41 \\
(38-43)\end{array}$ & $\begin{array}{c}34 \\
(32-37)\end{array}$ & $\begin{array}{c}40 \\
(38-43)\end{array}$ & $\begin{array}{c}40 \\
(37-43)\end{array}$ & $\begin{array}{c}50 \\
(48-53)\end{array}$ \\
\hline Infant mortality/ 100 births & $\begin{array}{c}14 \\
(12-16)\end{array}$ & $\begin{array}{c}13 \\
(11-15)\end{array}$ & $\begin{array}{c}13 \\
(11-15)\end{array}$ & $\begin{array}{c}13 \\
(11-14)\end{array}$ & $\begin{array}{c}10 \\
(8-12)\end{array}$ & $\begin{array}{c}10 \\
(8-12)\end{array}$ & $\begin{array}{c}9 \\
(7-11)\end{array}$ \\
\hline $\begin{array}{l}\text { Maternal mortality/ } 100 \\
\text { pregnancies }\end{array}$ & $\begin{array}{c}1.4 \\
(0.8-2.2)\end{array}$ & $\begin{array}{c}1.0 \\
(0.5-1.7)\end{array}$ & $\begin{array}{c}0.9 \\
(0.4-1.5)\end{array}$ & $\begin{array}{c}0.9 \\
(0.4-1.6)\end{array}$ & $\begin{array}{c}0.6 \\
(0.2-1.2)\end{array}$ & $\begin{array}{c}0.7 \\
(0.3-1.3)\end{array}$ & $\begin{array}{c}0.6 \\
(0.2-1.2)\end{array}$ \\
\hline Immunization $/ 100$ boys & $\begin{array}{c}60 \\
(57-63)\end{array}$ & $\begin{array}{c}73 \\
(70-76)\end{array}$ & $\begin{array}{c}85 \\
(82-88)\end{array}$ & $\begin{array}{c}88 \\
(86-91)\end{array}$ & $\begin{array}{c}77 \\
(74-79)\end{array}$ & $\begin{array}{c}95 \\
(93-96)\end{array}$ & $\begin{array}{c}90 \\
(88-92)\end{array}$ \\
\hline Immunization/100 girls & $\begin{array}{c}57 \\
(53-60)\end{array}$ & $\begin{array}{c}64 \\
(61-68)\end{array}$ & $\begin{array}{c}67 \\
(63.70)\end{array}$ & $\begin{array}{c}69 \\
(66-73)\end{array}$ & $\begin{array}{c}74 \\
(71-77)\end{array}$ & $\begin{array}{c}77 \\
(73-80)\end{array}$ & $\begin{array}{c}80 \\
(76-83)\end{array}$ \\
\hline $\begin{array}{l}\text { Detection of mental } \\
\text { disorders } / 1000 \text { men } \\
\text { at risk }\end{array}$ & $\begin{array}{c}0.4 \\
(0.7-0.6)\end{array}$ & $\begin{array}{c}9 \\
(7-10)\end{array}$ & $\begin{array}{c}7 \\
(5-6)\end{array}$ & $\begin{array}{c}10 \\
(8-11)\end{array}$ & $\begin{array}{c}7 \\
(6-8)\end{array}$ & $\begin{array}{c}11 \\
(10-13)\end{array}$ & $\begin{array}{c}13 \\
(11-14)\end{array}$ \\
\hline $\begin{array}{l}\text { Detection of mental } \\
\text { disorders } / 1000 \text { women } \\
\text { at risk }\end{array}$ & $\begin{array}{c}0.2 \\
(0-0.5)\end{array}$ & $\begin{array}{c}8 \\
(7-9)\end{array}$ & $\begin{array}{c}8 \\
(7-9)\end{array}$ & $\begin{array}{c}9 \\
(8-10)\end{array}$ & $\begin{array}{c}7 \\
(6-9)\end{array}$ & $\begin{array}{c}10 \\
(9-11)\end{array}$ & $\begin{array}{c}12 \\
(11-13)\end{array}$ \\
\hline $\begin{array}{l}\text { Psychotropic prescriptions } \\
1000 \text { men at risk }\end{array}$ & $(0-0.5)$ & $\begin{array}{c}8 \\
(7-9)\end{array}$ & $\begin{array}{c}6 \\
(5-7)\end{array}$ & $\begin{array}{c}7 \\
(6-8)\end{array}$ & $\begin{array}{c}6 \\
(5-6)\end{array}$ & $\begin{array}{c}9 \\
(8-10)\end{array}$ & $\begin{array}{c}11 \\
(10-13)\end{array}$ \\
\hline $\begin{array}{l}\text { Psychotropic prescriptions } \\
1000 \text { women at risk }\end{array}$ & (s) $\begin{array}{l}0.2 \\
(0-0.4)\end{array}$ & $\begin{array}{c}7 \\
(6-8)\end{array}$ & $\begin{array}{c}5 \\
(4-6)\end{array}$ & $\begin{array}{c}8 \\
(7-9)\end{array}$ & $\begin{array}{c}7 \\
(6-8)\end{array}$ & $\begin{array}{c}8 \\
(7-9)\end{array}$ & $\begin{array}{c}11 \\
(9-12)\end{array}$ \\
\hline
\end{tabular}

$95 \%$ confidence intervals are shown between brackets.

$P H C=$ primary health care.

Both subdistricts are conservative communities, with low literacy rates. Decisionmaking is the province of men and women need the permission of their men-folk to access services. Therefore, a change in men's attitude, suggested by their increased use of PHC services, may account for the increased use of maternal and child health services by women. Likewise, the earlier increase in immunization of boys 
Table 1 (oonoluded)

\begin{tabular}{|c|c|c|c|c|c|c|}
\hline \multirow[t]{2}{*}{ Variable } & \multicolumn{6}{|c|}{ Comparison subdistrict:Taxilla } \\
\hline & 1986 & 1987 & 1988 & 1999 & 1990 & 1991 \\
\hline $\mathrm{PHC}$ attendance $/ 1000$ men & 559 & 612 & 531 & 492 & 436 & 397 \\
\hline $\begin{array}{l}\text { PHC attendance } 11000 \\
\text { women }\end{array}$ & 889 & 1020 & 1237 & 1270 & 1194 & 1011 \\
\hline $\begin{array}{l}\text { Pregnancies } 1000 \\
\text { women aged } \\
20-54 \text { years }\end{array}$ & $\begin{array}{c}184 \\
(173-195)\end{array}$ & $\begin{array}{c}209 \\
(197-220)\end{array}$ & $\begin{array}{c}221 \\
(209-232)\end{array}$ & $\begin{array}{c}210 \\
(199-222)\end{array}$ & $\begin{array}{c}202 \\
(191-213)\end{array}$ & $\begin{array}{c}231 \\
(220-242)\end{array}$ \\
\hline $\begin{array}{l}\text { Antenatal care } / 100 \\
\text { births }\end{array}$ & $\begin{array}{c}58 \\
(55-60)\end{array}$ & $\begin{array}{c}57 \\
(55-60)\end{array}$ & $\begin{array}{c}56 \\
(5358)\end{array}$ & $\begin{array}{c}66 \\
(6468)\end{array}$ & $\begin{array}{c}60 \\
(5863)\end{array}$ & $\begin{array}{c}62 \\
(60 \quad 64)\end{array}$ \\
\hline $\begin{array}{l}\text { Assisted deliveries/100 } \\
\text { births }\end{array}$ & $\begin{array}{c}28 \\
(26-31)\end{array}$ & $\begin{array}{c}27 \\
(25-30)\end{array}$ & $\begin{array}{c}27 \\
(25-29)\end{array}$ & $\begin{array}{c}41 \\
(39-41)\end{array}$ & $\begin{array}{c}39 \\
(37-41)\end{array}$ & $\begin{array}{c}43 \\
(41-45)\end{array}$ \\
\hline Infant mortality/100 births & $\begin{array}{c}13 \\
(11-15)\end{array}$ & $\begin{array}{c}13 \\
(11-15)\end{array}$ & $\begin{array}{c}12 \\
(10-14)\end{array}$ & $\begin{array}{c}11 \\
(9-12)\end{array}$ & $\begin{array}{c}10 \\
(9-11)\end{array}$ & $\begin{array}{c}10 \\
(8-11)\end{array}$ \\
\hline $\begin{array}{l}\text { Matemal mortality/ } 100 \\
\text { pregnancies }\end{array}$ & $\begin{array}{c}2.2 \\
(1.3-3.4)\end{array}$ & $\begin{array}{c}1.8 \\
(1.1-2.8)\end{array}$ & $\begin{array}{c}1.0 \\
(0.9-2.5)\end{array}$ & $\begin{array}{c}1.6 \\
(0.9-2.5)\end{array}$ & $\begin{array}{c}1.3 \\
(0.6-2.1)\end{array}$ & $\begin{array}{c}1.3 \\
(0.7-2.1)\end{array}$ \\
\hline Immunization/100 boys & $\begin{array}{c}61 \\
(58-65)\end{array}$ & $\begin{array}{c}61 \\
(57-64)\end{array}$ & $\begin{array}{c}64 \\
(61-68)\end{array}$ & $\begin{array}{c}68 \\
(65-71)\end{array}$ & $\begin{array}{c}70 \\
(67-73)\end{array}$ & $\begin{array}{c}72 \\
(69-75)\end{array}$ \\
\hline Immunization $/ 100$ girls & $\begin{array}{c}59 \\
(55-61)\end{array}$ & $\begin{array}{c}62 \\
(59-66)\end{array}$ & $\begin{array}{c}64 \\
(61-67)\end{array}$ & $\begin{array}{c}66 \\
(63-69)\end{array}$ & $\begin{array}{c}69 \\
(66-72)\end{array}$ & $\begin{array}{c}71 \\
(68-73)\end{array}$ \\
\hline $\begin{array}{l}\text { Detection of mental } \\
\text { disorders } / 1000 \text { men } \\
\text { at rick }\end{array}$ & $\begin{array}{c}0.3 \\
(0.1-0.6)\end{array}$ & $\begin{array}{c}0.6 \\
(0.2-1)\end{array}$ & $\begin{array}{c}1.0 \\
0.42)\end{array}$ & $\begin{array}{c}1.0 \\
(0.4-2)\end{array}$ & $\begin{array}{c}0.6 \\
(0.2-1)\end{array}$ & $\begin{array}{c}0.7 \\
(0.3-1)\end{array}$ \\
\hline $\begin{array}{l}\text { Detection of mental } \\
\text { disorders } / 1000 \text { women } \\
\text { at risk }\end{array}$ & $\begin{array}{c}0.3 \\
(0-0.5)\end{array}$ & $\begin{array}{c}0.4 \\
(0-0.8)\end{array}$ & $\begin{array}{c}0.6 \\
(0-1.1)\end{array}$ & $\begin{array}{c}0.8 \\
(0.3-1.3)\end{array}$ & $\begin{array}{c}0.3 \\
(0-0.6)\end{array}$ & $\begin{array}{c}1.2 \\
(0.6-1.8)\end{array}$ \\
\hline $\begin{array}{l}\text { Psychotropic prescriptions/ } \\
1000 \text { men at risk }\end{array}$ & $\begin{array}{c}0.2 \\
(0-0.4)\end{array}$ & $\begin{array}{c}0.4 \\
(0-0.7)\end{array}$ & $\begin{array}{c}0.5 \\
(0.1-1)\end{array}$ & $\begin{array}{c}0.7 \\
(0.2-1.1)\end{array}$ & $\begin{array}{c}0.4 \\
(0-0.7)\end{array}$ & $\begin{array}{c}0.3 \\
(0-0.6)\end{array}$ \\
\hline $\begin{array}{l}\text { Psychotropic prescriptions/ } \\
1000 \text { women at risk }\end{array}$ & $\begin{array}{c}0.3 \\
(0-0.6)\end{array}$ & $\begin{array}{c}0.3 \\
(0-0.5)\end{array}$ & $\begin{array}{c}0.3 \\
(0-0.6)\end{array}$ & $\begin{array}{c}0.5 \\
(0-0.8)\end{array}$ & $\begin{array}{c}0.3 \\
(0-0.6)\end{array}$ & $\begin{array}{c}0.7 \\
(0.3-1.2)\end{array}$ \\
\hline
\end{tabular}

95\% confidence intervals are shown between brackets.

$P H C=$ primary health care.

may be explained in terms of prevalent attitudes. A son is considered more precious than a daughter; a son is usually viewed as a future breadwinner of the family and inheritance passes to the male offspring.
In conclusion, our study provides evidence that integrating mental health into primary care services has potential bencfits that extend beyond a mere increase in detection and treatment rates for mental ill-

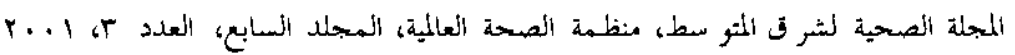


nesses. Mental health is the spearhead that can take PHC beyond Health for All by the
Year 2000 and far into the new millennium.

\section{References}

1. Primary Health Care: Report of the International Conference on Primary Health Care, Alma Ata, USSR, 6-12 September. Jointly sponsored by the World Health Organization and the United Nation's Children's Fund. Geneva, World Health Organization, 1978.

2 Sartorius $\mathbf{N}$. The limits of mental health care in general medical services. In: Tansella M, Thornicroft $\mathrm{G}$, eds. Common mental disorders in primary care. London, Routledge, 1999:211-21.

3. Seventh Five Year Plan (1988-93) and Perspective Plan (1980-2003): report of the sub-working group on mental health care in Pakistan. Islamabad, Planning Commission, Government of Pakistan, 1987.

4. Mubbashar MH et al. Community-based mental health care programme. Report of an experiment in Pakistan. Eastern
Mediterranean Region health services journal, 1986, 1:14-20.

5. Goldberg D. Round the World, Pakistan. Revolution in mental health care. Lancet, 1987, 2:736.

6. Goldberg D. Round the World, India and Pakistan. Community psychiatry. Lancet, 1992, 339:113-4.

7. Goldberg D. A quantum leap for community psychiatry. Lancet, 1989, 335:14456.

8. Mubbashar $\mathrm{MH}$ et al. Promotion of mental health through school health programmes. Eastern Mediterranean Region health services journal, 1989, 6:14-9.

9. Rahman $A$ et al. Through the eyes and ears of the community: the impact of the School Mental Health Programme in rural Rawalpindi, Pakistan. Lancet, 1990, 352(9133):1022-5. 